\title{
Efek Liberalisasi di ASEAN bagi Indonesia sebagai Negara Dunia Ketiga
}

\author{
Dwi Adiyanti ${ }^{1}$ \\ Jurusan Ilmu Hubungan Internasional, Universitas Potensi Utama Medan \\ Email: ardiyanti.1987@gmail.com
}

\begin{abstract}
Abstrak
Kerjasama antar Negara anggota ASEAN yang terangkum dalam Masyarakat Ekonomi ASEAN (MEA) merupakan salah satu praktek liberalisasi. MEA yang terangkum dalam empat pilar memiliki dampak signifikan terhadap arah kerjasama antara sepuluh Negara anggota ASEAN. Arah kerjasama dalam peningkatan ekonomi dan pembangunan merupakan sebuah langkah terpadu dari masing-masing Negara anggota untuk kemajuan komunitas regional di Asia Tenggara. ASEAN sebagai sebuah komunitas regional semakin meningkatkan kiprahnya untuk ikut bersaing dan meningkatkan kerjasama di tingkat regional khususnya dan global pada umumnya. Dalam praktek kerjasama tersebut, terlihat ada usaha dari berbagai Negara untuk ikut berpartisipasi dalam persaingan ini. Tujuan besar untuk memajukan perekonomian di kawasan Asia Tenggara mendapat respon positif dari semua Negara anggota dengan membentuk Masyarakat Ekonomi ASEAN. Namun, dengan berbagai macam masalah perekonomian di masing-masing Negara anggota ASEAN, kerjasama dalam lingkup MEA ini membawa dampak liberalisasi yang tidak semua bisa diikuti oleh Negara anggota ASEAN yang masih tergolong dalam Negara dunia ketiga, salah satunya adalah Indonesia.
\end{abstract}

Kata kunci: masyarakat ekonomi ASEAN (MEA), negara dunia ketiga, liberalisasi, kerjasama

\begin{abstract}
The cooperation conducted among ASEAN member states which is encapsulated in Asean Economic Community (AEC) is one of liberalization practices. AEC consists of four important pillars which gives significant impact on cooperation between them, especially in economic and development. The cooperation focus on increasing economic and development in each member states which also needs strong commitment as a regional community in Southeast Asia. ASEAN as a regional community keep increasing its capability to accelerate the cooperation in the regional and global level at the same time. In the end, we might see effot from each state to participate. However, each state must cope with their own domestic problems, such as politic, economic, and development. This research will prove that cooperation AEC creates wave of liberalization among ASEAN member states which is not easy to cope with, for example Indonesia which is still included in the third world countries list.
\end{abstract}

Keywords: ASEAN Economic Community (AEC), third world country, liberalization, and cooperation

\footnotetext{
${ }^{1}$ Staff pengajar Ilmu Hubungan Internasional di Universitas Potensi Utama Medan
} 


\section{Konsep Kerjasama Liberalisasi antar Negara Anggota ASEAN}

Kerjasama antar negara anggota ASEAN merupakan sebuah kemajuan besar dalam kajian Ilmu Hubungan Internasional. ASEAN yang merupakan sebuah komunitas regional sekarang semakin berkembang dengan peningkatan kerjasama ekonomi antar Negara anggota ASEAN. Tak jarang, sebagai sebuah komunitas regional, ASEAN harus menghadapi berbagai konflik bersamaan dengan semakin meningkatnya permintaan akan pertumbuhan ekonomi di wilayah tersebut. Kajian tentang perdebatan prinsip non-intervensi dalam resolusi konflik antar negara anggota ASEAN, kini cenderung mengarah ke kajian tentang kerjasama ekonomi dan pola pertahanan antar negara anggota ASEAN. Kerjasama ekonomi antar Negara ASEAN tentu dilihat sebagai hal yang potensial akan membawa peningkatan ekonomi di wilayah Asia Tenggara, seperti tulisan Vinayak HV et al (2014), "The ten member states of the Association of Southeast Asian Nations collectively comprise the seventhlargest economy in the world". Negara anggota ASEAN secara keseluruhan termasuk dalam peringkat ke tujuh di dunia. Negara anggota ASEAN seperti diketahui ada 10 negara yang terdiri dari Indonesia, Singapura, Malaysia, Thailand, Kamboja, Laos, Vietnam, Filipina, Brunei Darussalam, dan Burma. Sebagian besar negara anggota ASEAN merupakan penyedia jasa tenaga kerja terbesar ketiga setelah China dan India, seperti yang ditulis dalam Vinayak HK et al (2014),
"Labor-force expansion and productivity improvements drive GDP growth-and ASEAN is making impressive strides in both areas. Home to more than 600 million people, it has a larger population than the European Union or North America. ASEAN has the third-largest labor force in the world, behind China and India".

Indonesia yang merupakan salah satu Negara anggota ASEAN menempati urutan keempat dalam jumlah populasi terbesar di dunia. Indonesia berpotensi untuk menjadi pesaing yang tangguh dalam menghadapi MEA juga besar. Namun, permasalahan daya saing kembali menjadi masalah mendasar bagi Indonesia untuk bersaing dalam MEA. Indonesia disebutkan belum siap menghadapi tantangan MEA 2015². Dalam Jurnal tersebut juga dimuat tulisan tentang ketidaksiapan empat negara lain (Singapura, Malaysia, Thailand, dan Filipina). Hasil temuan tersebut mengungkapkan bahwa Indonesia masih perlu meningkatkan komitmen dari para pemegang saham untuk mendapatkan keuntungan ekonomi dalam MEA. Sesuai dengan hasil penelitian sebelumnya, juga ditemukan adanya jarak perbedaan dalam jumlah keuntungan ekonomi antar Negara anggota ASEAN yang tergabung dalam MEA $^{3}$. Berikut ini adalah

\footnotetext{
${ }^{2}$ International journal economic and finance. Vol.4 no 11. Asean Economic Corporation: Trade Liberalization Impacts on The National Economy.2012 pdf

${ }^{3}$ Ibid
} 
data jumlah tenaga kerja dan pengangguran di

Indonesia ${ }^{4}$ :

\section{Tabel 1: Indikator Pasar Buruh Utama}

\section{(2013-2015)}

\begin{tabular}{|l|l|l|l|l|l|l|}
\hline $\begin{array}{l}\text { Indikator } \\
\text { Utama }\end{array}$ & $\begin{array}{l}\text { Februari } \\
2013\end{array}$ & $\begin{array}{l}\text { Agustus } \\
2013\end{array}$ & $\begin{array}{l}\text { Februari } \\
2014\end{array}$ & $\begin{array}{l}\text { Agustus } \\
2014\end{array}$ & $\begin{array}{l}\text { Februari } \\
2015\end{array}$ & $\begin{array}{l}\text { Agustus } \\
2015\end{array}$ \\
\hline $\begin{array}{l}\text { Populasi total } \\
\text { (juta jiwa) }\end{array}$ & 247.7 & 249.4 & 251.0 & 252.7 & 254.4 & 256.0 \\
\hline $\begin{array}{l}\text { Populasi usia } \\
\text { (15 tahun } \\
\text { (juta jiwa) }\end{array}$ & 178.1 & 180.0 & 181.2 & 183.0 & 184.6 & 186.1 \\
\hline $\begin{array}{l}\text { Populasi aktif } \\
\text { secara } \\
\text { ekonomi (juta } \\
\text { jiwa) }\end{array}$ & 123.2 & 120.2 & 125.3 & 121.9 & 128.3 & 122.4 \\
\hline $\begin{array}{l}\text { Bekerja (juta } \\
\text { jiwa) }\end{array}$ & 115.9 & 112.8 & 118.2 & 114.6 & 120.8 & 144.8 \\
\hline $\begin{array}{l}\text { Tidak bekerja } \\
\text { (juta jiwa) }\end{array}$ & 7.2 & 7.4 & 7.2 & 7.2 & 7.5 & 7.6 \\
\hline $\begin{array}{l}\text { Tidak aktif } \\
\text { secara } \\
\text { ekonomi }\end{array}$ & 56.0 & 59.8 & 55.9 & 61.1 & 56.3 & \\
\hline
\end{tabular}

\footnotetext{
${ }^{4}$ Indonesia investment.com http://www.indonesiainvestments.com/finance/macroeconomicindicators/unemployment/item255 diakses 23 Agustus 2016

Catatan: Data tersebut termasuk dalam usaha pertambangan, pabrik, perlengkapan, dan pembangunan (konstruksi)
} 
Tabel 2: Data Jumlah Tenaga Kerja Indonesia

\begin{tabular}{|l|l|l|l|l|l|l|l|}
\hline \multicolumn{1}{|c|}{ Tahun } & \multicolumn{1}{|c|}{$\mathbf{2 0 1 0}$} & $\mathbf{2 0 1 1}$ & $\mathbf{2 0 1 2}$ & $\mathbf{2 0 1 3}$ & $\mathbf{2 0 1 4}$ & $\mathbf{2 0 1 5}$ & $\mathbf{2 0 1 6}$ \\
\hline $\begin{array}{l}\text { Jumlah } \\
\text { tenaga kerja }\end{array}$ & 116.5 & 119.4 & 120.3 & 120.2 & 121.9 & 122.4 & 127.8 \\
\hline Bekerja & 108.2 & 111.3 & 113.0 & 112.8 & 114.6 & 114.8 & 120.8 \\
\hline $\begin{array}{l}\text { Tidak } \\
\text { Bekerja }\end{array}$ & 8.3 & 8.1 & 7.3 & 7.4 & 7.2 & 7.6 & 7.0 \\
\hline
\end{tabular}

Kedua data tersebut menjelaskan bahwa kebutuhan akan bidang industri masih besar untuk menyerap tenaga kerja sebesar 127.8 juta jiwa, menandakan bahwa Indonesia masih tergantung pada adanya modal/investasi asing. Penekanan angka pengangguran di Indonesia merupakan sebuah upaya keras dari pemerintah Indonesia, yaitu mengadakan berbagai kerjasama dengan Negara industri dan memaksimalkan penguatan perekonomian dalam negeri melalui program kewirausahaan ${ }^{5}$ yang didukung oleh koperasi dan UMKM (Usaha Mikro Kecil dan Menengah).

\section{Posisi Indonesia dan Dampak Kerjasama Antar Anggota ASEAN}

Dalam kondisi seperti ini, sebagian besar negara anggota ASEAN memiliki masalah demografi yang secara signifkan mempengaruhi pertumbuhan ekonomi di wilayah tersebut. Oleh karena itu, negara

${ }^{5}$ http://staff.uny.ac.id/sites/default/files/penelitian/D rs.\%20Sukidjo,\%20M.Pd./PERAN\%20KEWIRAU SAHAAN\%20DALAM\%20MENGATASI\%20PE NGANGGURAN\%20DI\%20INDONESIA.pdf diakses 24 Agustus 2016 dengan sumber daya manusia yang tinggi membutuhkan kerja sama dengan negara industri untuk menyerap tenaga kerja tersebut hingga mampu meningkatkan perekonomian di negara tersebut. Salah satunya adalah Indonesia, yang masih memiliki sebutan negara dunia ketiga (Mochtar Masoed, 2003). Indonesia yang tergolong dalam negara dunia ketiga dianggap masih belum siap untuk menghadapi tantangan menjadi bagian dari MEA. Sampai sekarang, Indonesia masih bergantung pada hutang luar negeri ${ }^{6}$. Selain itu, Indonesia juga masih menghadapi masalah wabah penyakit seperti demam berdarah dan ledakan populasi ${ }^{7}$. Dengan keadaan masih terbebani hutang, Indonesia masih terus melakukan pembangunan jangka panjang. Setelah memasuki era MEA 2015, Indonesia masih terus menjadi sebuah negara yang berkewajiban memajukan perekonomian di

\footnotetext{
${ }^{6}$ Kementrian Keuangan Dirjen Anggaran dan Manajemen Resiko

2015.http://www.djppr.kemenkeu.go.id/uploads/file s/dmodata/in/5Statistik/BSPUN\%20\%28Govt $\% 20$ Debt\%20Profile\%29\%20edisi\%20Maret\%202015_ eng\%281\%29.pdf diakses 7 September 2016 ${ }^{7}$ Indonesia termasuk sebagai Negara keempat dengan populasi terbanyak di dunia.
} 
tingkat regional yaitu wilayah Asia Tenggara, dengan melakukan kerjasama dengan sesama negara anggota ASEAN. Namun, di saat yang sama, Indonesia juga meghadapi masalah lonjakan populasi dan peningkatan beban anggaran yang digunakan untuk tunjangan maupun pembangunan.

Indonesia yang memiliki posisi penting di kalangan anggota ASEAN merupakan pemasok sumber tenaga kerja dan juga pasar dari posisi strategis. Di sisi lain, masyarakat Indonesia juga merupakan konsumen produk, dengan perilaku konsumtif yang dimiliki dan juga pasar bebas seperti diterapkan sekarang ini. Sehingga, Indonesia merupakan sebuah pasar dan konsumen potensial menguntungkan di saat yang bersamaan. Seperti yang disebutkan dalam penelitian McKinsey \& Company “Indonesia's population is young, growing and rapidly urbanizing, making it one of the fastestgrowing consumer markets in the world".

Penelitian tersebut juga menjelaskan bagaimana perilaku penduduk di Indonesia yang semakin konsumtif didukung dengan perkembangan media sosial ${ }^{8}$. Dengan perilaku konsumtif yang didukung oleh perkembangan pemasaran melalui dunia sosial, semakin membuka pintu kerjasama. Ditambah lagi, perdagangan bebas yang membuat masyarakat Indonesia hampir tidak menemui kendala yang berarti untuk mendapatkan barang dari luar negeri. Kemudahan akses dan akses

\footnotetext{
${ }^{8}$ http://www.omron.id/img/pdf/id/Indonesia\%20Co nsumer\%20Report\%202014.pdf diakses 24 Agustus 2016
}

perdagangan yang tidak lagi mampu dibendung dari dunia sosial membuat Indonesia semakin harus berhati-hati dalam menetapkan kebijakan dalam dan luar negeri. ${ }^{9}$

Diantara Negara anggota ASEAN, Indonesia adalah salah satu negara penyumbang GDP sebesar $33 \%{ }^{10}$. Tentu posisi ini bukan sebuah hal yang mudah bagi negara berkembang yang juga masih bergantung atas investasi negara maju, atau negara dunia ketiga. Atas dukungan investasi asing, peningkatan pembangunan dan kemudahan akses untuk melakukan perdagangan di dalam dan ke luar negeri, merupakan langkah Indoensia menuju tahapan liberalisasi. Hal ini tidak hanya terjadi di Indonesia, mengingat adanya ASEAN+ 3 dengan adanya posisi Korea, China dan Jepang.

Perpindahan buruh antar negara angggota ASEAN dalam MEA merupakan salah satu praktek liberalisasi. Masing-masing negara yang terdaftar dalam MEA melakukan konsep" freedom of movement". Hampir serupa dengan Uni Eropa (UE), MEA mengijinkan adanya kebebasan akses buruh untuk bekerja ke Negara anggota dalam konteks "skilled labor" ". Mereka yang berprofesi menjadi buruh ahli dan berketerampilan diperkenankan bekerja ke Negara lain sesama anggota

\footnotetext{
${ }^{9}$ Lus Ambarwati. Jurnal: Indonesia Overview of AEC 2015: What Doea The AEC Mean for Foreign Investors pdf 2015

ihttp://www.ina.or.id/images/stories/magazine/2016 -Jan/Asean-Economic-Community.pdf diakses 1 September 2016

${ }^{10}$ Ibid

${ }^{11}$ Pasha L Hsieh Journal: Examining The Liberalization of ASEAN 's Legal Services Market: Challenge and Reforms
} 
ASEAN dan Negara tujuan tidak boleh melakukan proteksionisme bagi buruh dalam negerinya. Oleh karena itu, keahlian masingmasing buruh sangat diperhatikan. Persaingan antar anggota ASEAN sangat ketat, masingmasing negara harus membekali warga negaranya dengan keahlian dan keterampilan agar tidak kalah saing dengan penduduk dari negara anggota ASEAN yang lain.

Seperti yang sudah dijelaskan, Indonesia merupakan negara dengan populasi terbanyak keempat di dunia. Indonesia juga merupakan salah satu negara dengan sumber daya manusia yang tinggi. Dengan hasil penelitian tersebut, praktek liberalisasi antar anggota ASEAN dalam hal perpindahan tenaga kerja terampil berpengaruh terhadap perkembangan perekonomian di Indonesia. Posisi Indonesia semakin diperhitungkan, yakni sebagai pasar tenaga kerja maupun konsumen produk olahan dari hasil tenaga kerja Indonesia yang potensial. Namun, negara anggota ASEAN masih memiliki sebuah masalah penting dalam melakukan liberalisasi melalui MEA, yaitu masalah pembagian pendapatan dinamis. Liberalisasi perdagangan di wilayah Asia Tenggara biasanya menekankan pendapatan dinamis untuk memperluas kesejahteraan dibanding efek statis (Thomas:2006). Maksudnya, dalam perdagangan bebas seperti MEA, sulit mencapai kesepakatan pembagian yang sesuai, mengingat di masing-masing negara mengalami naik turun perekonomian. Maka, untuk menyelenggarakan perdagangan bebas di wilayah Asia Tenggara, hal ini tidak mudah.
Hal penting untuk digaris bawahi adalah adanya kesanggupan dari Negara anggota ASEAN untuk bersama-sama meningkatkan perekonomian dan pembangunan secara berkesinambungan secara regional.

Liberalisasi yang berlangsung terus menerus dianggap sebagai liberalisasi yang tidak terpadu, karena penguasa sebelumnya kurang menekankan dampak perdagangan (Thomas:2006). Kerjasama antar negara anggota ASEAN sudah lama dimulai, bahkan sebelum adanya Masyarakat Ekonomi ASEAN. Misalnya, kerjasama antara Indonesia dengan Filipina telah menghapus tarif di bidang ekspor impor karet, perawatan kesehatan, tekstil, barang berbahan dasar kayu dan otomotif sejak 2008 dan $2009^{12}$.

Peningkatan kerjasama antar anggota ASEAN terus dikembangkan, salah satunya di bidang pariwisata. Indonesia bekerja sama dengan Negara anggota ASEAN yang lain, misalnya Malaysia, untuk mempromosikan potensi pariwisata, yang juga didukung oleh PBB melalui penandatanganan ASEAN Tourism Agreement ${ }^{13}$.

Menurut penulis, pariwisata disadari sebagai sebuah komoditi yang penting untuk peningkatan devisa, maka pembangunan infrastruktur untuk memudahkan akses ke wilayah pariwisata merupakan dukungan dari sektor perhubungan dan perdagangan. Seperti

\footnotetext{
12 Thomas A Zimmerman. Journal: Trade Liberalization in Souh East Asia. 2006. Jerman ${ }^{13}$ UN. ASEAN Toursim Agreement. 2012. http://asean.org/?static_post=asean-tourismagreement diakses 25 Agustus 2016
} 
yang dikutip dari situs Kemenpar berikut ini "Kalau sektor pariwisata tumbuh, maka industri perhubungan, kerajinan dan industri kreatif bakal tumbuh. Pariwisata itu adalah sektor yang bisa menjadi sumber devisa, dan pada suatu saat nanti terbesar di Tanah Air," kata Rizal usai pertemuan dengan Menteri Pariwisata Arief Yahya dan Gubernur DKI Jakarta, Basuki Tjahaja Purnama, Rabu (19/8) lalu ${ }^{14}$. Jika semua Negara anggota ASEAN melakukan langkah serupa, bisa dibayangkan kemudahan akses yang mendukung pariwisata dan kemudian mengarah pada kemajuan investasi di sepuluh Negara anggota ASEAN. Indonesia yang diakui memiliki kekayaan alam, memiliki salah satu dari tujuh keajaiban dunia dan juga menjadi Negara yang dikenal luas sebagai tempat yang ramah penduduk lokalnya menjadi tujuan para turis mancanegara yang favorit. Hal ini ditunjukkan dari peningkatan jumlah turis mancanegara yang berkunjung ke Indonesia. Hal ini tentu saja merupakan sebuah kabar baik bagi Indonesia.

Namun, kerjasama dalam bidang pariwisata masih harus terus diikuti dengan pembangunan insrastruktur. Dengan kata lain, pariwisata merupakan salah satu cara untuk menggenjot pertumbuhan di sektor lain. Sehingga, menurut penulis pemerintah harus terus melakukan modifikasi kebijakan dalam hal anggaran untuk mendukung kerjasama di bidang pariwisata tersebut. Jumlah penduduk

\footnotetext{
${ }^{14}$ Kemenpar: Pariwisata Kini Jadi Andalan Pendulang Devisa Negara http://www.kemenpar.go.id/asp/detil.asp?c=16\&id= 2959 diakses 25 agustus 2016
}

bekerja dan angka kelahiran maupun kematian merupakan masalah lain yang dihadapi berbanding terbalik dengan kebutuhan anggaran untuk pembangunan di wilayah Indonesia. Tidak berhenti sampai disitu, permasalah bidang pembangunan masih terus berkutat pada pembebasan tanah dan wilayah pertanian yang semakin menipis karena kebutuhan pembangunan infrastruktur. Maka, pola kehidupan masyarakat tradisional yang ada di sekitar tempat pariwisata juga mengalami perubahan, yaitu transformasi menjadi masyarakat urban. 
Berikut ini data resmi dari kementrian Pariwisata mengenai jumlah turis mancanegara ke Indonesia ${ }^{15}$ :

Tabel 3: Kunjungan Turis Mancanegara ke Indonesia

JUMLAH KUNJUNGAN WISATAWAN MANCANEGARA MENURUT PINTU MASUK DAN KEBANGSAAN

Bulan Juli 2016

\begin{tabular}{|c|c|c|c|c|c|c|c|c|c|c|c|c|c|c|c|c|c|c|c|c|c|c|c|c|}
\hline \multirow{2}{*}{ No. } & \multirow{2}{*}{ KEBangsaAN } & \multirow{2}{*}{$\begin{array}{c}\text { Kose } \\
\text { Negara }\end{array}$} & \multicolumn{19}{|c|}{ PINTU MASUK UTAMA } & \multicolumn{2}{|c|}{ 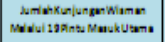 } & \multirow{2}{*}{ Netumbitan } \\
\hline & & & 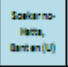 & $\mid$ & 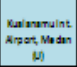 & 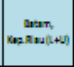 & 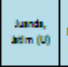 & 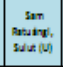 & $\left|\begin{array}{c}\operatorname{ming} \\
\operatorname{mar}(0)\end{array}\right|$ & 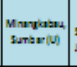 & 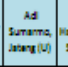 & 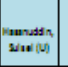 & $\mid \begin{array}{c}\text { atc } \\
\text { Natu(n) }\end{array}$ & 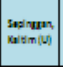 & 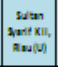 & 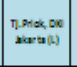 & $\mid \lim _{x \in \sin (2)}$ & 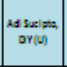 & 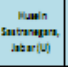 & 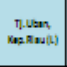 & 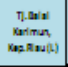 & 2016 & 2015 & \\
\hline$:$ & scaser & 90 & (13) & 8 & 817 & $\frac{40}{40}$ & 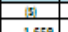 & 97 & 7 & (1) & \begin{tabular}{|l|}
$\theta_{1}$ \\
1
\end{tabular} & (15) & (ii) & (ii) & (t) & (a) & (is) & 10 & (a) & (a) & (10) & & & \\
\hline 2 & 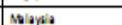 & vis & & 12543 & 8938 & & & & 1.998 & 3776 & 329 & & & & 183 & + & $+3,2+2$ & 901 & $1,, 005$ & $3,4,9$ & 2,435 & 93,060 & 96,189 & .3.8. \\
\hline 1 & board & $s$ & 18,953 & 18,221 & 108 & & & 94 & 4 & 10 &. & 6 & 3, & 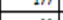 & 1,778 & $\dot{0}$ & 1,256 & 3,326 & 5,434 & 1,155: & 4,547 & 85,451 & 77,627 & 10.08 \\
\hline 4 & & 8 & & & & 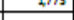 & & & & & & & 85 & 11 & 7 & + & 21 & 166 & 122 & 761 & 4 & 40,917 & 40,236 & 1.65 \\
\hline$:$ & & s, & $12,7 \%$ & & & & & & & & & $\cdot$ & 202 & 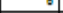 & & + & 33 & 148 | & 73 & 543 & & 31,502 & 28,583 & 10.2. \\
\hline & & the & 6,281 & 10,916 ] & 285 & .21 & 1,014 | & 11 & 49 & 2 & 8 & 1 & 22 & 1 & 28 & $\dot{.}$ & 55 & 33 & 32 & 2000 & 16 & 19,556 & 21,455 & .8.98 \\
\hline & Thersibe & $m \varepsilon$ & 27,020 & \begin{tabular}{|c|}
100,995 \\
\end{tabular} & 755 & 3232 & 1,651 & 6,018 & 24 & 55 & 3 & 28 & 756 & 1,108 & 43 & . & 256 & $3 n$ & 155 & 4,358 & 60 & 146,504 & 119,376 & 22.72 \\
\hline 7 & Hea & 100 & 7,845 & 14,394 & 222 & 4575 & 538 & 6 & 10 & 11 & 2 & 6 & 63 & 54 & 72 & $\cdot$ & 251 & 218 & 115 & 914 & 259 & 29,555 & 20,368 & 45.11 \\
\hline 8 & Miging & sim & 4,592 & 3,126 & 185 & 3037 & 293 & 45 & 12 & 2 & 7 & 9 & 26 & 16 & 21 & $\cdot$ & 120 & 135 & 67 & 833 & 97 & 12,629 & 10,674 & 18.32 \\
\hline 2 & Hoskons & $7 \times 0$ & 2,595 & 3,391 & 93 & 338 & 326 & 141 & 25 & 2 &. & 6 & 47 &. & 5 &. & 19 & 36 & 36 & 708 & 1 & 7,819 & 7,359 & 6.1 .1 \\
\hline 80 & Bailand & $7 \pi$ & 3,410 & 2,958 & 290 & 400 & 1,360 & 35 & 1 & 27 & 6 & 11 & 157 & 4 & 34 & $\dot{.}$ & 16 & 402 & 152 & 148 & 45 & 9,457 & 6,000 & 55.54 \\
\hline \begin{tabular}{l|l}
11 \\
\end{tabular} & Awali & su & 5,978 & \begin{tabular}{|l|l|}
108,228 \\
\end{tabular} & 437 & 21,54 & 235 & 110 & 26 & \begin{tabular}{l|l}
321 \\
\end{tabular} & 2 & 29 & 168 & 76 & 27 & 1 & 47 & 145 & 114 & 1,262 & 17 & 118,399 & 90,961 & 30.15 \\
\hline 12 & \begin{tabular}{|l|} 
Austia Sertiat \\
\end{tabular} & usta & 8,548 & 15,033 & 364 & 1203 & 959 & 90 & 7 & \begin{tabular}{l|l}
61 & \\
\end{tabular} & 3 & 37 & 192 & 35 & 40 & . & 39 & 278 & 149 & 369 & 12 & 27,569 & 23,169 & 18.99 \\
\hline \begin{tabular}{l|l}
13 \\
\end{tabular} & Ingeris & 100 & 6,341 & 22,251 & 398 & 1,685 & 205 & 80 & 12 & \begin{tabular}{l|l}
58 \\
\end{tabular} &. & 31 & 555 & 25 & 17 & . & 100 & 354 & 95 & 632 & 10 & 32,840 & 27,794 & 18.15 \\
\hline 14 & saratas & 8.0 & 12,298 & 15,269 & 1,251 & 451 & 222 & 68 & 29 & 59 & 4 & 68 & 251 & 10 & 18 & . & 17 & 370 & 88 & 69 &. & 30,552 & 27,423 & 11.4. \\
\hline$: 19$ & Drman & Ant & 4,911 & 15,134 & 447 & 345 & 229 & 150 & 10 & 23 & . & 72 & 383 & 33 & 12 & . & 39 & 309 & 59 & 267 & 5 & 22,429 & 18,599 & 20.59 \\
\hline \begin{tabular}{l|l|}
$: 4$ \\
\end{tabular} & Nanosis & $m s$ & 7,876 & 21,968 & 282 & 552 & 212 & 65 & 8 & 94 & 1 & 102 & 391 & 16 & 4 & . & 115 & 742 & 68 & 289 & 70 & 32,855 & 25,725 & 27.72 \\
\hline 21 & Ris & NS & 778 & 3,734 & 21 & 124 & 23 & 9 & $\cdot$ &. & $\cdot$ & $\cdot$ & 54 & 2 & $\cdot$ & $\cdot$ & 6 & 30 & 1 & 87 & 1 & 4,870 & 5,164 & .5 .69 \\
\hline $\begin{array}{ll}8 \\
\end{array}$ & 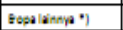 & $\cdot$ & 15,136 & 44,237 & 1,018 & 1.183 & 578 & 338 & 15 & \begin{tabular}{l|l|}
85 \\
\end{tabular} & 2 & \begin{tabular}{l|l|l}
88 \\
\end{tabular} & 799 & 52 & 42 & . & 78 & 1,377 & 127 & 562 & 142 & 65,950 & & \\
\hline $\begin{array}{ll}a \\
\end{array}$ & Sod katia & so & 29,242 & 1,452 & 18 & 13 & 14 &. &. & 9 & . & . & 16 & . &. & . & 25 &. & 39 & 2 & $\cdot$ & 30,830 & 22,137 & 39.27 \\
\hline 20 & \begin{tabular}{|l|} 
Mwit \\
\end{tabular} & Mes & 718 & 776 & 19 & 28 & $\cdot$ & . & 1 & 2 & 1 & $\cdot$ & 1 & $\cdot$ & 1 & $\cdot$ & $\cdot$ & 8 & 5 & $\cdot$ & 1 & 1,561 & 780 & 100.13 \\
\hline $2 \pm$ & Ui Eniratkab & ten & 1,098 & 265 & 3 & 1 & 55 & $\cdot$ & $\cdot$ & . & 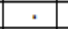 & $\cdot$ & 2 & $\cdot$ & $\cdot$ & . &. &. & 3 & . &. & 1,428 & 1,457 & .2 .65 \\
\hline 22 & Sarin & $\operatorname{sen}$ & 181 & 165 & 1 & 4 & $\cdot$ & . & $\cdot$ & $\cdot$ & $\cdot$ & $\cdot$ & $\cdot$ & $\cdot$ & $\cdot$ & $\cdot$ & $\cdot$ & . & $\cdot$ & $\cdot$ & $\cdot$ & 351 & 158 & 122.15 \\
\hline \begin{tabular}{l|l|}
23 & \\
\end{tabular} & Kwail" & KNT & 740 & 299 & . & 4 & 5 & . & . & . & . & . & . & . & . & . & . & 2 & 2 & . & . & 1,052 & & \\
\hline 24 & $\tan 0^{\circ}$ & $W N$ & 943 & 63 & 24 & 5 & 10 & 1 & . & . & . & 4 & 1 & 2 & . & . & . & 1 &. & . & . & 1,054 & & \\
\hline 29 & Qsi $x^{\circ}$ & ant & 118 & 141 & $\cdot$ & 9 &. & $\cdot$ & $\cdot$ & . & $\cdot$ & . & 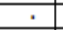 & . & . & $\cdot$ & $\cdot$ & $\cdot$ & 1 & $\cdot$ & $\cdot$ & 269 & & \\
\hline 25 & ans. & oun & 2,328 & 183 & . & D & 3 & . & . & 1 & . & . & . & . & . & . & . & . & 21 & . & . & 2,553 & & \\
\hline & Linnya"*) & $\cdot$ & 31,063 & 47,761 & 2,590 & 15,337 & \begin{tabular}{l|l|}
7,1499 \\
\end{tabular} & 271 & \begin{tabular}{l|l|l}
157 & \multicolumn{1}{|c|}{} \\
\end{tabular} & 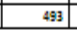 & 405 & 226 & \begin{tabular}{ll|}
1,540 \\
\end{tabular} & 185 & 513 & \begin{tabular}{l|l|l}
4,252 & \\
\end{tabular} & 149 & 2,273 & 1,313 & 1,437 & 43 & 117,278 & 132,585 & \\
\hline \multicolumn{3}{|c|}{ Jumian 2016} & \begin{tabular}{|l|}
240,135 \\
\end{tabular} & 455,332 & 18,902 & 209,939 & 22,010 & 7,731 & \begin{tabular}{|l|l|}
2,397 & \\
\end{tabular} & \begin{tabular}{l|l|l|l|l|l|}
4,12 & \\
\end{tabular} & $m$ & \begin{tabular}{l|l|l|l|l|l|}
1,432 & \\
\end{tabular} & \begin{tabular}{ll|}
9,698 & \\
\end{tabular} & 1,877 & 2,858 & 4,253 & 6,970 & 11,732 & 9,776 & 20,626 & 7,819 & 968,216 & 804,521 & 20.35 \\
\hline \multicolumn{3}{|c|}{ Jumian 2015} & 190,244 & \begin{tabular}{|l|}
335,141 \\
\end{tabular} & 16,774 & 1117,353 & \begin{tabular}{l|l|}
18,245 \\
\end{tabular} & 2,069 & \begin{tabular}{l|l|}
2,573 \\
\end{tabular} & \begin{tabular}{l|l|l|}
3,011 \\
\end{tabular} & \begin{tabular}{l|l|}
542 \\
\end{tabular} & \begin{tabular}{l|l|l|l|l|l|}
1,194 & \\
\end{tabular} & \begin{tabular}{l|l}
5,341 \\
\end{tabular} & 797 & 2,934 & \begin{tabular}{l|l|}
3,951 \\
\end{tabular} & 6,521 & 5,235 & 6,619 & 28,385 & 7,572 & & & \\
\hline \multirow{2}{*}{\multicolumn{3}{|c|}{ Pertumbuhan (*x) }} & 26.22 & 26.01 & 12.09 & 6.40 & 20.64 & \begin{tabular}{|l|}
270.08 \\
\end{tabular} & 6.84 & 37.56 & 43.36 & \begin{tabular}{|l|l|}
19.93 \\
\end{tabular} & 81.58 & 135.51 & 2.25 & 7.54 & 6.89 & 124.11 & 47.70 & .27 .33 & 3.26 & & & \\
\hline & & & \multicolumn{19}{|c|}{ KUNJUNGAN WISMAN MELALUI PINTU MASUK LAINNYA *") } & 64,525 & 73,063 & .11 .69 \\
\hline & & & & & & & TOTAL K & KUNJUNG & GAN WISM & MAN MELAL & ALUI SEURR & RUH PINTU & U MASUK & & & & & & & & & 1032,741 & 877,584 & 17.68 \\
\hline
\end{tabular}

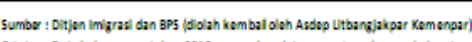

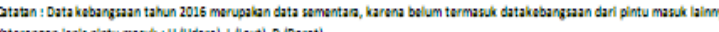

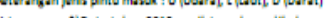

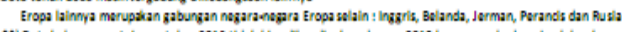

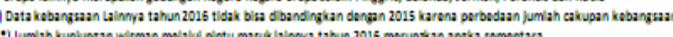

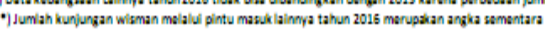

\footnotetext{
${ }^{15}$ Kemenpar. Data Kunjungan turis mancanegara ke
}

Indonesia.http://www.kemenpar.go.id/userfiles/Lapbul\%20Juni\%202016_klasik.pdf diakses 7 September 2016 
Di sisi lain, menurut penulis, dengan kemudahan akses akan berdampak pada peningkatan kunjungan yang luar biasa dari turis domestik maupun non domestik. Kegiatan perdagangan di sekitar tempat pariwisata akan menjadi salah satu cara peningkatan pendapatan daerah. Langkah ini berdampak pada masyarakat sekitar tempat wisata yang akan semakin terbiasa dengan komunikasi dalam bahasa asing, tidak terkecuali dengan sentuhan budaya asing. Hal ini tentu akan berpengaruh terhadap budaya dan gaya hidup masyarakat. Jika tidak mampu membendung arus perubahan, yang terjadi adalah pergeseran nilai budaya luhur yang sudah ada sejak lama di wilayah tersebt. Di Bali, misalnya, kearifan lokal berbasis agama dan adat masih sangat dijaga. Hal ini dilakukan guna menjaga masyarakat maupun tempat wisata yang ada di Bali dari gempuran perubahan yang terus diakibatkan oleh peningkatan pembangunan fisik. Terbukti, kerjasama yang dilakukan Indonesia, sebagai sebuah entitas Negara berimbas kepada peningkatan perekonomian daerah.

Pariwisata dan pembangunan adalah dua hal yang tidak dapat dipisahkan.
Pariwisata alam, di satu sisi menampilkan keelokan alam dan masyarakat yang masih hidup secara tradisional. Di sisi lain, pembangunan akses yang mendukung kenyamanan para wisatawan adalah hal penting dilakukan. Kenyamanan jalan hingga potensi pembangunan rumah atau wahana wisata yang menyediakan tempat tinggal berunsur alam adalah sisi lain dari pariwisata. Masih menurut penulis, dalam tahapan penyusunan kebijakan publik, pemerintah akan dihadapkan pada permasalah kearifan lokal yang didukung oleh sebagian masyarakat, dan masalah peningkatan ekonomi dengan cara pembebasan lahan yang didukung sebagian masyarakat yang lain, yang sudah penat menghadapi sulitnya merasakan pendidikan yang layak hingga mendapatkan penghasilan yang cukup karena kesulitas akses yang selama ini dihadapi. Pembangunan yang bersebelahan dengan pariwisata tersebut, yang kemungkinan besar menjadi sebuah jalan keluar bagi masyarakat tersebut. Sulitnya mempertahankan kearifan lokal yang berseberangan dengan tantangan efek pembangunan merupakan kajian Ilmu Hubungan Internasional yang terus menarik untuk dikaji selama ini. 


\section{Unsur Penting Dalam Kerjasama ASEAN}

Beberapa pemahaman penting tentang ASEAN sekilas sudah dijelaskan di atas. ASEAN yang merupakan sebuah kesatuan regional negara-negara di kawasan Asia Tenggara memiliki beberapa karakteristik dalam menjalin hubungan. Selama ini Negara anggota ASEAN mengalami diskriminasi yang cukup lama dari Negara-negara maju. Dengan sebagian besar Negara anggotanya adalah Negara berkembang, ASEAN dan juga Negara bekas jajahan Negara maju.

Namun, seiring dengan pergantian pemerintahan dan rejim di masing-masing Negara anggota ASEAN, kajian Ilmu Hubungan Internasional tentang ASEAN mengalami perkembangan. Kajian keilmuan tidak lagi berfokus pada pembahasan pemecahan kkonflik antar Negara anggota ASEAN dengan prinsip non intervensi, namun lebih mengarah pada kesatuan Negara anggota ASEAN dalam meningkatkan perekonomian dan pembangunan secara nyata di lingkup regional. Di samping itu, kajian Ilmu Hubungan Internaisonal terus menyoroti adanya dukungan secara ekonomi maupun pertahanan nasional dari Negara di luar ASEAN, misalnya Korea, China, dan Jepang. Negara maju seperti Amerika ${ }^{16}$, yaitu pengaruh Negara maju tersebut dalam peningkatan kerjasama di bidang ekonomi, sosial, budaya, pertahanan dan keamanan. Menurut penulis,

\footnotetext{
${ }^{16}$ Dukungan Lembaga AS untuk ASEAN. https://id.usembassy.gov/id/our-relationshipid/dukungan-lembaga-as-untuk-asean/ diakses 26 Agustus 2016
}

ada banyak pertimbangan yang perlu dilakukan, diantaranya:

1. Rasa persaingan antar Negara anggota ASEAN yang selama ini masih menjadi bayang-bayang Negara maju, kebergantungan Negara anggota ASEAN dengan Negara maju di luar ASEAN dan menimbulkan persaingan power diantara Negara maju maupun Negara dunia ketiga tersebut ${ }^{17}$

2. Belum adanya sebuah sistem yang tuntas dalam menyelesaikan masalah di ASEAN sebagai komunitas regional, misalnya konflik yang pecah antara beberapa Negara anggota ASEAN dengan China dalam kasus Laut China Selatan

3. Masing-masing Negara anggota ASEAN mengalami masa lalu rejim yang berpengaruh terhadap kebijakan luar negeri di Negara tersebut, misalnya: konflik Indonesia dengan Malaysia (wilayah Sipadan dan Ligitan) yang terjadi sejak $1989^{18}$.

\footnotetext{
${ }^{17}$ Persaingan Negara ASEAN Menghadapi MEA. http://www.rri.co.id/post/editorial/383/editorial/pers aingan_negara_negara_asean_menghadapi_mea.ht $\mathrm{ml}$ diakses 26 Agustus 2016

${ }^{18}$ Tribunnews. Ternyata ini Penyebab Sipadan Dan Ligitan lepas dari Indonesia. 2015 http://makassar.tribunnews.com/2015/02/15/ternyat a-ini-penyebab-sipadan-dan-ligitan-lepas-dariindonesia diakses 26 Agustus 2016
} 
Dalam tulisan lain, dijelaskan bahwa ASEAN merupakan sebuah komunitas dengan kekuatan ekonomi yang cukup besar (Vinayak, et al:2014). Seperti diketahui, kerjasama ASEAN sudah lama digagas dan pada akhir tahun 2015 resmi diumumkan Masyarakat Ekonomi ASEAN (MEA) ${ }^{19}$. Langkah ini merupakan wujud nyata Negara anggota ASEAN yang setuju untuk bergabung dalam komunitas regional untuk memajukan perekonomian dan pembangunan di wilayah Asia Tenggara. Berikut ini empat pilar $\mathrm{MEA}^{20}$ :

1. Pasar tunggal dan basis Produksi

2. Kawasan berdaya saing ekonomi tinggi

3. Pembangunan ekonomi yang merata

4. Integrasi dengan ekonomi global

Kerjasama dan persaingan adalah dua hal yang tidak bisa dilepaskan dari inetgrasi pasar bebas ASEAN atau yang disebut dengan Masyarakat Ekonomi ASEAN (MEA). Kerjasama yang dilakukan oleh seluruh Negara anggota ASEAN adalah sebuah kemajuan besar dalam lingkup regional Asia Tenggara. Namun, kerjasama ini menimbulkan permasalahan baru bagi Negara anggota ASEAN untuk terus menyiapkan sumber daya yang dimiliki. Maksimalisasi potensi sumber daya adalah sebuah kewajiban bagi setiap Negara anggota ASEAN agar mampu bersaing satu sama lain.

${ }^{19}$ ASEAN Economic Community Blueprint. 2008. http://asean.org/wp-content/uploads/archive/518710.pdf diakses 26 Agustus 2016

\footnotetext{
${ }^{20}$ ASEAN Economic Community Blureprint. 2008.http://asean.org/wp-

content/uploads/archive/5187-10.pdf diakses 26 Agustus 2016
}

Cakupan kerjasama yang merupakan sebuah sisi lain dari persaingan ditanggapi sebagai tantangan baru dalam bidang ekonomi, sosial, dan politik. Tantangan ini akan mampu dijawab oleh setiap Negara anggota ASEAN dengan cara dan kebijakannya sendiri.

Misalnya, dalam bidang kebudayaan, dengan adanya pilar pasar tunggal dan basis produksi bagi Masyarakat Ekonomi ASEAN, masingmasing Negara anggota ASEAN harus terus meningkatkan daya saing warga negaranya. Kemudahan akses dari masing-masing Negara anggota ASEAN membuat gebrakan untuk meningkatkan devisa. Salah satunya adalah Indonesia, dengan kebijakan bebas visa ${ }^{21}$ ke Negara anggota ASEAN lain. Hal ini berdampak positif dengan bertambahnya kunjungan turis mancanegara maupun domestik. Kunjungan dari Negara Indonesia ke Singapura dan sebaliknya adalah salah satu bukti dampak positif MEA $^{22}$, dan kebijakan tersebut berdampak terhadap peningkatan kesejahteraan warga di daerah maupun peningkatan pembangunan fisik.

Bisa dibayangkan jika setiap Negara di ASEAN menerapkan gebrakan untuk menarik investasi, maka yang terjadi adalah peningkatan pertumbuhan ekonomi secara regional. Di sisi lain, kita bisa melihat dari

\footnotetext{
${ }^{21}$ DEJ-Udom\& Asociates. Jurnal: Legal and Bussines Intelligence. Work Permits and Visas for Foreign Workers in ASEAN Countries pdf.2014 ${ }^{22}$ Singapore Tourism Board. Jurnal: Indonesia, STB Market Insights https://www.stb.gov.sg/statistics-and-marketinsights/marketinsights/stb\%20market\%20insights $\% 20$ $\%$ 20indonesia.pdf?AspxAutoDetectCookieSupport $=1$ diakses 31 Agustus 2016
} 
semakin meningkatnya keinginan belajar ke luar negeri. Dengan kemudahan akses dan peningkatan di sector pariwisata, penduduk di Indonesia juga dituntut untuk meningkatkan daya saingnya. Salah satunya adalah pembelajaran bahasa asing yang semakin dituntut sejak sekolah dasar. Hal ini dirasa penting dilakukan oleh pemerintah. Dengan peningkatan jumlah wisatawan yang masuk ke Indonesia, otomatis penggunaan bahasa asing sudah menjadi kebutuhan dasar bagi penduduk yang berada di sekitar tempat wisata tersebut.

Peningkatan daya saing juga dilakukan di bidang yang lain, salah satunya adalah kemampuan bekerja. Semakin banyaknya sekolah menengah kejuruan dan pelatihan yang dilakukan, ditujukan untuk memenuhi tuntutan kinerja yang baik bagi penduduk di Indonesia. Hal ini dilakukan karena semakin besar arus masuk dari luar negeri yang menjadikan Indonesia sebagai lahan untuk mencari mata pencaharian. Dalam kasus masuknya buruh China $^{23}$ ke Indonesia, misalnya, masuknya para pekerja tenaga kasar di Indonesia dianggap sebagai sebuah masalah serius yang harus ditangani secara bijak. Di satu sisi, langkah ini akan menjadi masalah penting bagi tenaga kerja kasar domestic karena mereka yang berada di sekitar wilayah tersebut justru kesulitas untuk mendapatkan pekerjaan sebagai buruh $^{24}$. Di sisi lain, kita harus menyikapi

\footnotetext{
${ }^{23}$ Tempo.co

https://m.tempo.co/read/news/2015/08/31/0936964

21/ribuan-buruh-cina-masuk-indonesia-ini-

penjelasan-menaker diakses 31 Agustus 2016

${ }^{24}$ Banten Raya.com

http://bantenraya.com/utama/13919--buruh-china-
}

perjanjian kerja yang dilakukan oleh pengusaha maupun pembuat kebijakan. Kebijakan China adalah bersedia menerima perjanjian kerjasama dengan Indonesia asalkan mereka diperbolehkan untuk mempekerjakan tenaga kerja yang mereka bawa dari Negara asalnya. Sekali lagi, persaingan dan kerjasama adalah dua sisi yang tidak dapat dipisahkan dari MEA.

Indonesia yang masih disebut dengan Negara dunia ketiga, masih kesulitan untuk mengikuti pola persaingan yang sekarang mau tidak mau harus dihadapi dengan sesama Negara anggota ASEAN. Selain belum menyiapkan tenaga kerja yang berdaya saing, Indonesia juga masih harus bergantung dengan modal yang dibawa dari investor asing untuk melakukan pembangunan. Secara entitas Negara, Indonesia terus melakukan peningkatan di bidang ekonomi, sosial, maupun budaya. MEA dianggap sebagai sebuah tantangan maupun sarana bagi Indonesia untuk memacu langkah ke depan, tentunya masih harus dengan cara bergantung dari investasi asing.

Kerjasama dengan China, Korea, maupun Jepang merupakan sebuah cara efektif untuk merangkul Negara maritim dalam memajukan investasi di bidang ekonomi, IPTEK, maupun budaya, sehingga kita tidak perlu lagi bergantung hanya pada investor Amerika Serikat maupun Uni Eropa. Dengan begitu, integrasi secara global akan lebih mudah dilakukan jika seluruh Negara anggota 
ASEAN telah melakukan tugasnya untuk memperbaiki dan meningkatkan perekonomian secara regional. Hasilnya, ASEAN sebagai komunitas regional sudah berintegrasi untuk mampu bersaing dengan komunitas regional lain di dunia, ataupun Negara lain. Lagi-lagi, kerjasama merupakan sisi lain dari persaingan. Persaingan secara global yang diawali dengan kerjasama, diaharapkan akan membentuk sebuah komunitas yang kuat dan mampu bertahan secara terintegrasi di tengah pergolalakan politik dan pergantian rejim di dunia. Seperti diketahui, kekuatan Amerika Serikat sebagai kekuatan penting yang ikut menentukan percaturan politik, ekonomi, maupun pertahanan keamanan di dunia, diharapkan tidak lagi terjadi.

Kajian Ilmu Hubungan Internasional mulai lebih menekankan pada kekuatan non-state actor $^{25}$, salah satunya adalah komunitas regional seperti kawasan Asia Tenggara.Melalui upaya peningkatan yang dilakukan oleh kesepuluh Negara anggota ASEAN, diharapkan seluruh Negara anggota tersebut bersama-sama memajukan kawasan Asia Tenggara baik dalam bidang ekonomi maupun sosial. Dengan begitu, arah untuk mencapai kesejahteraan global dapat dicapai dengan lebih optimal.

\section{Kesimpulan}

Praktek liberalisasi oleh masing-masing negara anggota ASEAN melalui MEA (Masyarakat Ekonomi ASEAN) merupakan

\footnotetext{
${ }^{25}$ Journal.

http://scholar.harvard.edu/files/danielyewmaolim/fil es/limvree_wp2013 0.pdf diakses 31 Agutus 2016
}

salah satu bentuk liberalisasi, yaitu dalam hal akses bebas bagi tenaga kerja untuk bekerja di negara anggota ASEAN yang lain. Kerjasama yang dilakukan antar anggota ASEAN juga berpengaruh terhadap berbagai aspek lain. Misalnya, dalam hal pembangunan, masingmasing Negara anggota ASEAN. Empat pilar penting yang menjadi dasar pembentukan MEA selama ini selalu diakitkan dengan kemandirian negara anggota ASEAN agar tidak lagi bergantung pada Negara maju atau Negara kaya. Melalui MEA seluruh Negara anggota ASEAN juga diharapkan mampu menjadi sebuah kekuatan ekonomi yang mampu bersaing dengan Negara kaya atau Negara maju yang tadinya menjadi sumber investasi Negara anggota ASEAN. Dalam hal pertahanan keamanan, ASEAN kini tidak lagi berkutat pada isu penguatan pertahanan di masing-masing Negara karena adanya ancaman dari negara anggota ASEAN yang lain. Dengan adanya kerjasama yang dibentuk dalam MEA, maka isu persaingan antar Negara anggota lebih baik dirangkum dalam agenda kerjasama.

Posisi penting Indonesia yang masih dijuluki negara dunia ketiga, sekarang beralih ke negara dengan sumber tenaga kerja dan potensi pasar yang besar di saat bersamaan. Pembangunan dan peningkatan perekonomian di tingkat nasional maupun regional menyisakan masalah tersendiri bagi Indonesia. Dalam hal perhubungan, Indonesia terus melakukan kerjasama dengan negara ASEAN+3 untuk pembangunan insfrastruktur, karena Indonesia masih harus terus 
menggenjot bidang pariwisata yang ketenagakerjaan yang menjadi sumber daya potensial untuk menambah devisa negara.

Kesiapan Indonesia masih terus menjadi masalah utama. Selain karena Indonesia merupakan salah satu negara kepulauan di ASEAN, Indonesia juga masih terikat hutang dengan negara non ASEAN yang lain. Oleh karena itu, keikutsertaan Indonesia dalam MEA di tingkat regional masih menjadi pekerjaan rumah tersendiri. Masih banyak pertimbangan berdampak besar dalam hal arah kebijakan dalam maupun luar negeri Indonesia yang mempengaruhi arah kerjasama Indonesia.

\section{DAFTAR PUSTAKA}

"Understanding ASEAN: Seven things you need to know", McKinsey\& Company http://www.mckinsey.com/industries/p ublic-sector/ourinsights/understanding-asean-seventhings-you-need-to-know diakses 23 Agustus 2016

Ambarwati, Lusi. "Indonesia Overview of AEC 2015: What Does The AEC Mean For Foreign Investors?" http://www.ina.or.id/images/stories/ma gazine/2016-Jan/Asean-EconomicCommunity.pdf diakses 1 September 2016

ASEAN Briefings. Understanding ASEAN's Free Trade Agreements. http://www.aseanbriefing.com/news/2 014/02/13/understanding-aseans-freetrade-agreements.html diakses 31 Agustus

ASEAN Tourism Strategic Plan: 2016-2025 http://www.asean.org/storage/2012/05/ ATSP-2016-2025.pdf diakses 31 Agustus 2016
Pembangunan infrastruktur, perumahan, hingga pembangunan non fisik yang dilakukan oleh pemerintah Indonesia diharapkan mampu menyeimbangkan tuntutan pembangunan fisik, peningkatan ekonomi, maupun perbaikan sumber daya manusia. Sebagai negara yang masih dilabeli Negara dunia ketiga, Indonesia selama ini masih bisa mengikuti alur persaingan di tingkat regional. Meskipun seringkali tampak dipaksakan, Indonesia terbukti mampu menjadi Negara yang mengoptimalkan pengolahan sumber daya alam yang dimiliki, tentunya dengan bantuan dari investasi asing.

ASEAN. ASEAN Economic Blueprint. http://asean.org/wpcontent/uploads/archive/5187-10.pdf diakses 26 Agustus 2016

Brown, Ronald C. "Labor Implications of TPP: A Game Changer?" http://www.eastwestcenter.org/sites/de fault/files/filemanager/pubs/pdfs/75Brown-rev20160510.pdf diakses 31 Agustus 2016

Charitonenko, Stephanie and Ismah Afwan, "Commercialization of Microfinance : (Indonesia)" Asian Development Bank. http://www.adb.org/sites/default/files/p ublication/27539/micro-ino.pdf diakses 24 Agustus 2016

DEJ-Udom \& Asociates. 2014. Journal: Legal and Bussines Intelligence. Work Permits and Visas for Foreign Workers in ASEAN Countries pdf.

Deloitte. Deloitte Consumer Insights Capturing Indonesia's latent markets. 
http://www2.deloitte.com/content/dam /Deloitte/jp/Documents/consumerbusiness/cp/jp-cp-middle-classindonesia-en.pdf diakses 24 Agustus 2016

Indonesia Investment. "Penggangguran di Indonesia" http://www.indonesiainvestments.com/finance/macroecono mic-indicators/unemployment/item 255 diakses 23 Agustus 2016

Mas'oed Mochtar. 2003. Ekonomi Politik Internasional dan Pembangunan. Yogyakarta: Pustaka Pelajar

McKinsey\&Company. The Evolving Indonesian Consumer. http://www.omron.id/img/pdf/id/Indon esia\%20Consumer\%20Report\%20201 4.pdf diakses 24 Agustus 2016
Siow Yue Chia, ADBI Institute, ADBI Working Paper Series, "The ASEAN Economic Community: Progress, Challenges, and Prospects"

UNWTO. "The Impact of Visa Facilitation in ASEAN Member States" https://www.wttc.org//media/files/reports/policyresearch/impact_asean.pdf diakses 31 Agustus 2016

Vinayak et al. 2008. Understanding ASEAN: Seven Things You Need To Know. 2014 ASEAN Economic Community Blueprint.

Zimmerman, Thomas A. 2006. Trade Liberalization in Souh East Asia. Jerman 